\title{
9. NEOGENE COCCOLITH STRATIGRAPHY, MID-ATLANTIC RIDGE, DEEP SEA DRILLING PROJECT LEG 45
}

\author{
David Bukry, United States Geological Survey, La Jolla, California
}

\section{INTRODUCTION}

Leg 45 of the Deep Sea Drilling Project, which began and ended at San Juan, Puerto Rico, November 1975 to January 1976, recovered 112 cores at two drilling sites, 395 and 396 (Figure 1). Only 27 cores were taken above the sediment/basalt contact, because the prime objective of Leg 45 was to investigate igneous oceanic crust. During Leg 46 coring was resumed at Site 396 (Dmitriev, et al., 1976) An additional 35 cores were cut, including four that contained sediment. Basal sediment at Site 395 contains the upper Miocene Amaurolithus primus Subzone of coccoliths, suggesting an age of $6.1(+1.6 /-1.2)$ m.y. (van Andel and Bukry, 1973). The basal sediment at Holes 396 and 396B contains the middle Miocene Discoaster exilis Zone of coccoliths, suggesting an age of 13.6 $( \pm 1.6)$ m.y. From the cores taken on Legs 45 and 46, 125 samples, including shipboard smear slides, were examined. Coccolith zonation of samples, summarized in Figure 2, follows Bukry (1973, 1975). Two new species of coccolith are described: Ceratolithus separatus n. sp. and Ceratolithus simplex n. sp.

\section{COMPARISON OF SITES 395 AND 396}

Coccoliths are abundant throughout the sedimentary sections at both Sites 395 and 396, which are $140 \mathrm{~km}$ west and $160 \mathrm{~km}$ east of the Mid-Atlantic Ridge axis, respectively. The assemblages are in general moderately etched, and on the basis of abundant discoasters and few Oolithotus, Hayaster, and Sphenolithus, are subtropical. Unfortunately, detailed biostratigraphic and paleoecologic analyses of the sediments are not possible, because most samples contain assemblages that are mixed as a result of original slump deposition in this tectonically unstable region and later drilling disturbance. Relatively few samples contain original intact pelagic assemblages typical of transoceanic biostratigraphic units (Figure 2). Middle and upper Pliocene assemblages are the most ambiguous at both sites; only the Discoaster tamalis Subzone and Cyclococcolithina macintyrei Subzone appear to be intervals of mainly pelagic accumulation during middle and late Pliocene. The normal pelagic assemblages of other intervals have been altered by the addition of reworked extinct species.

\section{SITE SUMMARIES}

SITE 395

(lat $22^{\circ} 45.35^{\prime} \mathrm{N}$, long $46^{\circ} 04.90^{\prime} \mathrm{W}$, depth $4484 \mathrm{~m}$ )

Site 395 is on the western flank of the Mid-Atlantic Ridge, on crust magnetized during magnetic anomaly 4 (about 7 million years ago) (Rabinowitz, Melson, et al., 1976). The complete sediment interval is a 93meter section of upper Miocene to Quaternary foraminifer-bearing coccolith ooze that rests on basaltic basement. The coccolith assemblages from the base of the sediment column are assigned to the upper Miocene Amaurolithus primus Subzone, $6.1(+1.6 /-1.2)$ m.y. old on the basis of calculations of coring error, intrazone uncertainty, and estimated ages for coccolith zones (van Andel and Bukry, 1973; Bukry, 1975).

The 10 cores recovered at Hole 395 and the 3 from Hole $395 \mathrm{~A}$ are characterized by sediment layers that were greatly disrupted-diapired, detached, injected by water, and swirled-by drilling operations. Shipboard scientists report that the disturbance was so pervasive that plans to do paleomagnetic measurements of the sediment were abandoned. The original pre-drilling sediments were interpreted to have been transported to the site by bottom currents or by slumping off surrounding ridges. Basalt sand and cobbles occur at some levels. The common to abundant occurrence of reworked coccoliths in most samples examined would support a hypothesis of persistent sediment sloughing from nearby ridges. Concentrations of similarly sized, detached discoaster rays in such samples as 395-9-2, 90 $\mathrm{cm}(77 \mathrm{~m})$ and $395 \mathrm{~A}-3, \mathrm{CC}(88 \mathrm{~m})$ may indicate winnowing or strong dissolution.

Reworking is so persistent and abundant that meaningful zonation can be applied to only a few relatively unmixed assemblages from the section. Because of drilling disturbance and in-hole slumping, however, these could be out of place with respect to adjacent assemblages. Mixing of assemblages is minor in one sample near the base of the section, 395-9, CC ( $84 \mathrm{~m})$, which contains short-ranged Amaurolithus bizzarus, A. tricorniculatus, and Ceratolithus acutus, in addition to longer ranging $A$. delicatus, $A$. primus, and $C$. sp. cf. $C$. rugosus. The conjunction of $A$. bizzarus and $C$. acutus indicates the lower Pliocene $C$. acutus Subzone. A. tricorniculatus s. str., considered to be most prominent in the lower Pliocene (Gartner and Bukry, 1975), is most common just above, in Sample 395-9-2, $90 \mathrm{~cm}$ (77 m).

Core 10 assemblages are more mixed and the sediment is disturbed, but the younger Amaurolithus bizzarus and A. tricorniculatus are missing. Samples 395-10$1,100 \mathrm{~cm}(85 \mathrm{~m})$ and $395-10-2,100 \mathrm{~cm}(86 \mathrm{~m})$ are further distinguished from higher samples by the meager to common presence of Discoaster quinqueramus and large Sphenolithus abies. Thus, the presence of such younger species as Ceratolithus rugosus is considered to result from drilling contamination, and the upper Miocene Amaurolithus primus Subzone is 


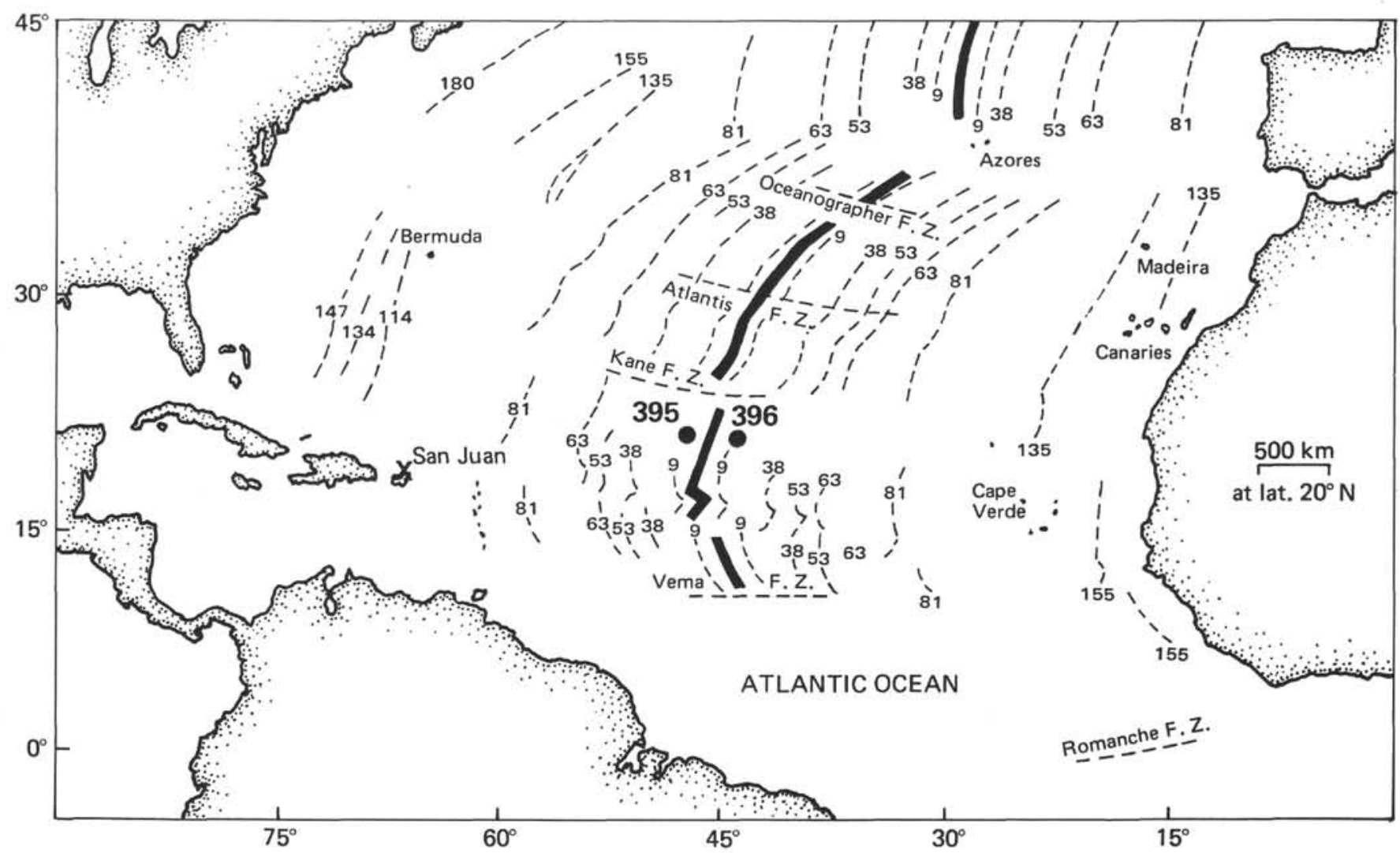

Figure 1. Location of sites drilled during Deep Sea Drilling Project Legs 45 and 46. Dashed lines with names are sea-floor fracture zones. Dashed lines with numbers are traces of significant magnetic anomalies; numbers are ages recorded in million years (Dmitriev, Heirtzler, et al., 1976).

identified. Because Core 10 contains the sediment/ basalt contact, the presence of $A$. primus Subzone species such as $D$. quinqueramus is a good indication for the maximum age of the contact sediment, regardless of down-hole mixing or up-core contamination by flowage near the core liner.

Interestingly, the oldest unmixed assemblage from the site was obtained in adjacent Hole 395A, Sample 395A-3-1, $126 \mathrm{~cm}(88 \mathrm{~m})$, from undisturbed sediment just above basalt. The upper Miocene Triquetrorhabdulus rugosus Subzone is identified in Sample 395A-3-1, $126 \mathrm{~cm}(88 \mathrm{~m})$, by the common occurrences of Amaurolithus delicatus, $A$. primus, and Triquetrorhabdulus rugosus. Discoaster variabilis is abundant, and $D$. quinqueramus and Ceratolithus rugosus are missing. The age of this sediment is therefore considered intermediate between that of Cores 9 and 10 ( 74 to $93 \mathrm{~m}$ ).

Among younger samples (395-8-5, $20 \mathrm{~cm}[70 \mathrm{~m}])$, a relatively unmixed assemblage of the Discoaster tamalis Subzone occurs above a sequence of samples (395$8, \mathrm{CC}[72 \mathrm{~m}]$ and Core 9 sections) containing Ceratolithus rugosus but lacking Discoaster tamalis. This suggests that the severely disturbed interval of Cores 4 to 8 is upper Pliocene. Two unmixed assemblages typical of the uppermost Pliocene Cyclococcolithina macintyrei Subzone, in Samples 395-2-5, $110 \mathrm{~cm}(15 \mathrm{~m})$ and 395$4-1,70 \mathrm{~cm}(27 \mathrm{~m})$, are dominated by Ceratolithus rugosus, Cyclococcolithina macintyrei, Discoaster brou- weri, and $D$. triradiatus. A correlative unmixed assemblage occurs in Sample 396-6-5, $66 \mathrm{~cm}(48 \mathrm{~m})$.

Discoaster brouweri and D. triradiatus are abundant in Sample 395-4-1, $70 \mathrm{~cm}$ (27 m). Ceratolithus rugosus is common, and the scarcity of Reticulofenestra pseudoumbilica and other older species suggests minimal reworking. Therefore, part of the sediment recovered by Core 4 is upper Pliocene Discoaster brouweri Zone, Cyclococcolithina macintyrei Subzone. Samples from Cores 5 to 7 ( 36 to $65 \mathrm{~m}$ ) are badly mixed but may be upper Pliocene, because samples from relatively undisturbed sediment of Core 8 , Sections 1, 2, 4, and 5 contain common Discoaster tamalis and rare or no Reticulofenestra pseudoumbilica or older reworked taxa such as Amaurolithus. Therefore, the lower upper Pliocene Discoaster tamalis Subzone is identified in Core 8.

The Miocene/Pliocene boundary, according to coccoliths, is between the Miocene Amaurolithus primus Subzone of Sample 395-10-1, $100 \mathrm{~cm}(85 \mathrm{~m})$, and the core-catcher sediments of Core $9(84 \mathrm{~m})$, which contain both the Ceratolithus rugosus Subzone (shipboard sample) and Ceratolithus acutus Subzone (shore-lab sample). Owing to the combination of original slumping and later mixing by drilling, the first and last occurrence sequences of coccoliths cannot be used effectively to locate the lower Pliocene/upper Pliocene boundary or the Pliocene/Quaternary boundary. Sam- 


\begin{tabular}{|c|c|c|c|c|c|c|}
\hline \multirow[b]{2}{*}{ Age } & \multirow[b]{2}{*}{ Zone } & \multirow[b]{2}{*}{ Subzone } & \multicolumn{2}{|c|}{ Site 395} & \multicolumn{2}{|c|}{ Site 396} \\
\hline & & & Mixed & Intact & Mixed & Intact \\
\hline \multirow{5}{*}{ 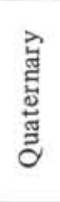 } & \multicolumn{2}{|l|}{ Emiliania huxleyi } & \multirow{3}{*}{$1-1,1-5,2 A-1$} & \multirow{3}{*}{$\begin{array}{l}1 \mathrm{~A}-2(2-3 \mathrm{~cm}) \\
2 \mathrm{~A}-2 / 2 \mathrm{~A}, \mathrm{CC}\end{array}$} & \multirow{3}{*}{$1-2,1 \mathrm{~A}-1$} & \\
\hline & \multirow{2}{*}{$\begin{array}{l}\text { Gephyrocapsa } \\
\text { oceanica }\end{array}$} & Ceratolithus cristatus & & & & \\
\hline & & Emiliania ovata & & & & $1, \mathrm{CC}$ \\
\hline & \multirow{2}{*}{$\begin{array}{l}\text { Crenalithus } \\
\quad \text { doronicoides }\end{array}$} & Gephyrocapsa caribbeanica & $2-1,1 \mathrm{~A}-2(105 \mathrm{~cm})$ & & $1-5,2-2,2-3,3-4$ & \\
\hline & & Emiliania annula & \multirow{7}{*}{$\begin{array}{l}2-2 / 7, \mathrm{CC} \\
{[36 \text { Samples }]}\end{array}$} & & \multirow{7}{*}{$\begin{array}{l}3, \mathrm{CC} / 12, \mathrm{CC} \\
\text { [39 Samples] }\end{array}$} & \\
\hline \multirow{8}{*}{$\begin{array}{l}\stackrel{8}{8} \\
\stackrel{\circ}{0}\end{array}$} & \multirow{4}{*}{$\begin{array}{l}\text { Discoaster } \\
\quad \text { brouweri }\end{array}$} & Cyclococcolithina macintyrei & & $2-5,4-1$ & & $6-5$ \\
\hline & & Discoaster pentaradiatus & & & & \\
\hline & & Discoaster surculus & & & & $8-2 / 8-5$ \\
\hline & & Discoaster tamalis & & $8-1 / 8-5$ & & $8-6$ \\
\hline & \multirow{2}{*}{$\begin{array}{l}\text { Reticulofenestra } \\
\text { pseudoumbilica }\end{array}$} & Discoaster asymmetricus & & & & \\
\hline & & Sphenolithus neoabies & & & & \\
\hline & \multirow{3}{*}{$\begin{array}{l}\text { Amaurolithus } \\
\text { tricorniculatus }\end{array}$} & Ceratolithus rugosus & & $8, \mathrm{CC} / 9, \mathrm{CC}$ & & $13-2 / 13, \mathrm{CC}$ \\
\hline & & Ceratolithus acutus & & $9, \mathrm{CC}$ & & \\
\hline \multirow{16}{*}{$\begin{array}{l}\stackrel{\Xi}{\mathscr{\Xi}} \\
\stackrel{0}{\Sigma}\end{array}$} & & Triquetrorhabdulus rugosus & $3 \mathrm{~A}, \mathrm{CC}$ & $3 \mathrm{~A}-1$ & & $1 \mathrm{~B}-1 / 2 \mathrm{~B}-1$ \\
\hline & \multirow{2}{*}{$\begin{array}{l}\text { Discoaster } \\
\quad \text { quinqueramus }\end{array}$} & A maurolithus primus & $10-1 / 10-2$ & & $3 \mathrm{~B}-1$ & 5-3 (Erratic) \\
\hline & & Discoaster berggrenii & & & & \\
\hline & \multirow{2}{*}{$\begin{array}{l}\text { Discoaster } \\
\text { neohamatus }\end{array}$} & Discoaster neorectus & & & & \\
\hline & & Discoaster bellus & & & & \\
\hline & \multirow{2}{*}{$\begin{array}{l}\text { Discoaster } \\
\quad \text { hamatus }\end{array}$} & Catinaster calyculus & & & & \\
\hline & & Helicosphaera carteri & & & & \\
\hline & \multicolumn{2}{|l|}{ Catinaster coalitus } & & & & \\
\hline & \multirow{2}{*}{$\begin{array}{c}\text { Discoaster } \\
\text { exilis }\end{array}$} & Discoaster kugleri & & & \multirow{2}{*}{$14-1 / 14-3$} & \multirow{2}{*}{$14-4 / 14-6,4 \mathrm{~B}-1$} \\
\hline & & Coccolithus miopelagicus & & & & \\
\hline & \multicolumn{2}{|c|}{ Sphenolithus heteromorphus } & & & & \\
\hline & \multirow{2}{*}{\multicolumn{2}{|c|}{$\begin{array}{l}\text { Helicosphaera ampliaperta } \\
\text { Sphenolithus belemnos }\end{array}$}} & & & & \\
\hline & & & & & & \\
\hline & \multirow{3}{*}{$\begin{array}{l}\text { Triquetrorhabdulus } \\
\quad \text { carinatus }\end{array}$} & Discoaster druggii & & & & \\
\hline & & Discoaster deflandrei & & & & \\
\hline & & -- & & & & \\
\hline
\end{tabular}

Figure 2. Neogene coccolith zonation of core samples from DSDP Legs 45 and Leg 46. If more than one sample is assigned to a zonal unit or interval, the highest and lowest samples are listed, separated by a slash. Cores from second or third drill holes at the same site are labeled $A$ and $B$. Core samples with obviously mixed assemblages that lack stratigraphic reliability are tabulated in a column separate from the few samples which have essentially unmixed assemblages. See text for explanation of erratic sample from Section 396-5-3.

ples with abundant reworked discoasters occur as high as Core 1. Gephyrocapsa oceanica, which evolved in the Quaternary (Hay et al., 1967), occurs in Cores 1, 2, $1 \mathrm{~A}$, and $2 \mathrm{~A}$, indicating a probable Quaternary date despite the mixture of Miocene (Amaurolithus amplificus) and Pliocene (Discoaster tamalis) species in many samples from these cores.

Two interbasalt limestone samples, 395-18-2, 57-58 $\mathrm{cm}(162 \mathrm{~m})$ and $395-18-2,60-62 \mathrm{~cm}(162 \mathrm{~m})$, are recrystallized and barren of coccoliths.

\section{SITE 396}

(lat $22^{\circ} 58.88^{\prime} \mathrm{N}$, long $43^{\circ} 30.95^{\prime} \mathrm{W}$, depth $4450 \mathrm{~m}$ )

Site 396 is on the western flank of the Mid-Atlantic Ridge, on crust magnetized between magnetic anomalies $5 \mathrm{a}$ and $5 \mathrm{~b}$ (about 11 to 16 million years ago). A 125-meter section of middle Miocene to Quaternary foraminifer-bearing coccolith ooze overlies basaltic basement. Coccolith assemblages from the base of the sedimentary section are assigned to the middle Miocene Discoaster exilis Zone, $13.6( \pm 1.6)$ m.y. old on the basis of calculations of intrazone uncertainty and estimated-age uncertainty for coccolith zones.
As at Site 395 , the 14 sediment-bearing cores from Hole 396, 2 from Hole 396A and 4 from Hole 396B, show significant reworking of coccoliths and sedimentary structures that indicate severe drilling disturbance. Both the reworking recorded in the original sediment and the later mixing by drilling operations contribute to the mixed assemblages in most samples. Biostratigraphic zonation must be limited to a few samples in which reworking and mixing were relatively minor.

The deepest sediment above basalt recovered at Hole 396, Core 14, and 150 meters farther west at Hole 396B, Core 4, is coccolith ooze and coccolith-rich brown clay containing the middle Miocene Discoaster exilis Zone. The lower three sections of Core 14 and the Core 4B sample contain an unmixed, moderately calcite-overgrown assemblage characterized by Coccolithus miopelagicus, C. pelagicus, Coronocyclus nitescens, Cyclicargolithus floridanus, Cyclococcolithina leptopora, C. macintyrei (elliptic center), Discoaster exilis, D. variabilis, Helicosphaera granulata, Reticulofenestra pseudoumbilica, Sphenolithus neoabies, and Triquetrorhabdulus rugosus. Core 4B has the only common C. floridanus and sparse Discoaster deflandrei, 
suggesting a portion of the D. exilis Zone older than is present in Core 14. The sediment of the upper three sections of Core 14 (Figure 3 ) is severely disturbed and mixed with a slurry of younger Miocene or Pliocene coccoliths. In addition to the taxa of the $D$. exilis Zone, these mixed assemblages include, as contaminants, Amaurolithus delicatus, A. primus, A. tricorniculatus, Ceratolithus rugosus, Discoaster brouweri, D. pentaradiatus, and D. surculus.

Like the lower part of Core 14, the Core 13 assemblages show little or no mixing or reworking. The coccoliths are moderately to strongly etched and are dominated by ortholithid genera Amaurolithus, Ceratolithus, and Discoaster, suggesting that the mixing in Core 14 resulted from drilling-induced slumping of material from the Core 13 interval directly above. Sample 396-13, CC $(117 \mathrm{~m})$ contains a solutionresistant assemblage of the lower Pliocene Ceratolithus rugosus Subzone, including Amaurolithus delicatus, $A$. primus, A. tricorniculatus, Ceratolithus rugosus, Cyclococcolithina leptopora, Discoaster asymmetricus, D. brouweri, D. pentaradiatus, D. surculus, D. variabilis, Reticulofenestra pseudoumbilica, Sphenolithus neoabies, and Triquetrorhabdulus rugosus. Solution-prone genera such as Discolithina, Helicosphaera, and Scyphosphaera are missing.

A late Miocene unconformity is implied at the level of the Core 13 to Core 14 boundary by (1) the great difference in biostratigraphic ages, (2) the mixing of contiguous fossil facies in the upper section of Core 14, and (3) the reworked occurrence of typical upper Miocene coccoliths, such as Discoaster berggrenii, $D$. neohamatus, and Minylitha convallis, through the younger Pliocene Cores (7, 9, and 12).

Coccoliths from several upper Miocene and lower Pliocene zones are mixed together in Cores 9 to 12 . Assemblages from Core 8 are relatively unmixed and contain lower upper Pliocene assemblages of the Discoaster brouweri Zone. Reticulofenestra pseudoumbilica is scarce, Sphenolithus is missing, and Discoaster pentaradiatus, D. tamalis, D. triradiatus, and D. surculus characterize the discoasters. Because of mixing, the sequence of discoaster extinctions used to divide the upper Pliocene into subzones cannot be used at Site 396. However, one unmixed sample, 396-6-5, $66 \mathrm{~cm}$ $(48 \mathrm{~m})$, contains the upper Pliocene Cyclococcolithina macintyrei Subzone, indicated by the conjunction of abundant Cyclococcolithina macintyrei and abundant delicately constructed Discoaster brouweri and $D$. triradiatus, which mask the trace (reworked?) of $D$. pentaradiatus present in the sample. Therefore, the $C$. macintyrei Subzone was probably drilled within the interval of Core 6.

Mixing is evident through Core 5, and only a general upper Pliocene Discoaster brouweri Zone assignment is indicated. A smear slide of a single dark brown clay bleb in Section 3, prepared aboard ship, contains an uncontaminated upper Miocene Amaurolithus primus Subzone assemblage, dominated by Discoaster variabilis. This sample, 396-5-3, $108 \mathrm{~cm}$ (37 m) (coccolith-rich clay), represents a coherent erratic of upper Miocene sediment that sloughed into the Site 396 basin during late Pliocene. Considering the presence of upper Miocene Discoaster neohamatus Zone species reworked in other Pliocene cores from Site 396, an exposed nearby source would be possible. None of the characteristic species that dominate the Miocene erratic (Amaurolithus amplificus, A. delicatus, D. variabilis) occur in subjacent Sample 396-5-3, 117 cm (37 m) (light yellowish brown coccolith ooze).

Core 4 is void, and Cores 1 to 3 contain Quaternary Gephyrocapsa species among an abundance of reworked Tertiary discoasters.

\section{COCCOLITH TAXONOMY}

Two new coccolith species are described. Other taxa which are cited but not discussed are listed alphabetically at the end of this section.

\section{Systematic Paleontology}

Genus CERATOLITHUS Kamptner, 1950

Ceratolithus separatus n. sp.

(Plate 1, Figures 1-16)

Description: Ceratolithus separatus has two thick tapering horns ornamented by distinct nodes or keels. The arch is very broad, rounded at the inner margin, and straight or concave at the outer margin. Instead of bending to join, the horns are extended in a subparallel alignment above the arch, accentuating the saddle-like appearance of the arch. In cross-polarized light, C. separatus is uniformly bright when the bisectrix is $45^{\circ}$ from the microscope polarization directions.

Remarks: Ceratolithus separatus is distinguished from C. rugosus Bukry and Bramlette and C. cristatus Kamptner s. str. by its wider and flat or concave arch. Also, the length and width of the $C$. separatus ceratolith are more nearly equal than in $C$. rugosus or $C$. cristatus. The horn tips are well separated, further distinguishing $C$. separatus from $C$. telesmus Norris or $C$. rugosus and $C$. cristatus. Thickly overgrown specimens may develop long spines around the periphery. Structurally, C. separatus is most similar to Amaurolithus amplificus (Bukry and Percival) and Ceratolithus armatus Müller. It may have evolved from lower Pliocene $C$. armatus, because they share similar crystallography.

Occurrence: Ceratolithus separatus is most common in upper Pliocene samples from Sites 395 and 396, especially $395-4-1,70 \mathrm{~cm}$ $(27 \mathrm{~m})$, where it is more common than $C$. rugosus. Because of mixing of assemblages, its natural range is not established, but it is most likely Pliocene, probably upper Pliocene.

Size: Maximum length 14 to $20 \mu \mathrm{m}$ (Holotype $16 \mu \mathrm{m}$ ).

Holotype: USNM 245105 (Plate 1, Figures 5, 6).

Isotypes: USNM 245106 to 245113.

Type locality: North Atlantic Ocean, DSDP Sample 396-7-2, 75 $\mathrm{cm}(54 \mathrm{~m})$.

\section{Ceratolithus simplex n. sp.}

(Plate 1, Figures 17-26)

Ceratolithus cristatus Kamptner, Bukry and Bramlette, 1968 (in part), Tulane Studies Geology, v. 6, p. 150, pl. 1, fig. 1 and 2.

Description: Ceratolithus simplex is a small, smooth, simple, hook-shaped microfossil. The arch and two horns are slender and nearly equal in diameter. Both horns lie in the same plane, and are equal to slightly subequal in length. In light microscopy, ornamentation such as keels or nodes are absent or indistinct. In cross-polarized light and plan view, the arch and horns are uniformly bright when the bisectrix is oriented $45^{\circ}$ to a polarization direction, and dark when aligned with a polarization direction.

Remarks: Ceratolithus simplex is distinguished from $C$. cristatus Kamptner s. str. by the more uniform diameter of its arch and horns, smaller size, wider interhorn opening, and lack of distinct keels and 


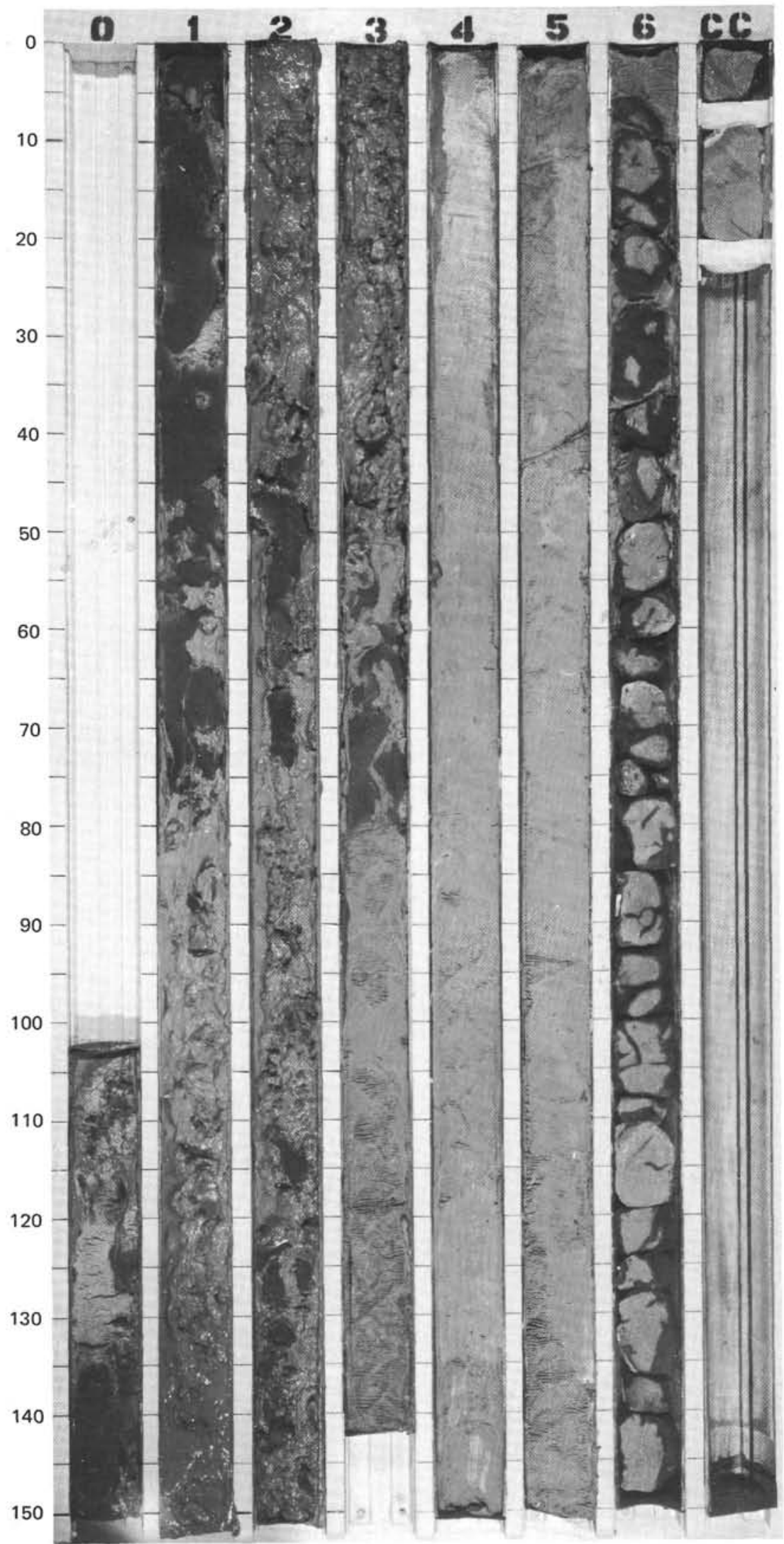

Figure 3. Middle Miocene sediments and basalt recovered in Core 14 at Deep Sea Drilling Project Hole 396. Upper Sections 1 to 3 contain noncoherent and severely disturbed sediment. Sediment in Sections 4 and 6 above the basalt is more cohesive and lacks the down-mixed Pliocene coccoliths that are common above. Scale in centimeters; sections numbered 0 to $C C$. 
nodes. The holotype of $C$. cristatus, specimens in the topotype material (Challenger 338), and other figured specimens such as Norris (1971, fig. 8), Hay and Beaudry (1973, pl. 2, fig. 1), and Gartner and Bukry (1975, fig. 4a-c), are distinctly larger and more robust and ornate than $C$. simplex. C. simplex is distinguished from C. telesmus Norris by its shorter, unappressed horns. The lack of distinct ornamentation on $C$. simplex is not considered to be a result of dissolution or overgrowth, because it occurs in several samples with nearly pristine well-ornamented specimens of $C$. cristatus.

Occurrence: Ceratolithus simplex occurs in Quaternary samples from Hole 395A, Cores 1 and 2, and Quaternary Sample 396-1, CC. Although it previously may have been recorded as long-ranging $C$. cristatus, $C$. simplex occurs in Pleistocene and Holocene fossil deposits, such as Sample 288-1-2, 50-51 cm, from the Pacific Ocean, suggesting it was transoceanic in distribution. Whether it is still living, like the larger forms $C$. cristatus or $C$. telesmus, has not been determined.

Size: Maximum length 8 to $12 \mu \mathrm{m}$ (Holotype $11 \mu \mathrm{m}$ ).

Holotype: USNM 245114 (Plate 1, Figures 19, 20).

Isotypes: USNM 245115 to 245120. $\mathrm{m})$.

Type locality: North Atlantic Ocean, DSDP Sample 396-1, CC (5

A. bizzarus (Bukry)

A. delicatus Gartner and Bukry

A. primus (Bukry and Percival)

A. tricorniculatus (Gartner)

Ceratolithus acutus Gartner and Bukry

C. armatus Müller

C. cristatus Kamptner

C. rugosus Bukry and Bramlette

C. telesmus Norris

Coccolithus miopelagicus Bukry

C. pelagicus (Wallich)

Coronocyclus nitescens (Kamptner)

Cyclicargolithus floridanus (Roth and Hay)

Cyclococcolithina leptopora (Murray and Blackman)

C. macintyrei (Bukry and Bramlette)

Discoaster asymmetricus Gartner

D. berggrenii Bukry

D. brouweri Tan

D. deflandrei Bramlette and Riedel

D. exilis Martini and Bramlette

D. neohamatus Bukry and Bramlette

D. pentaradiatus Tan

D. quinqueramus Gartner

D. surculus Martini and Bramlette

D. tamalis (Kamptner)

D. triradiatus Tan

D. variabilis Martini and Bramlette

Gephyrocapsa oceanica Kamptner

Helicosphaera granulata (Bukry and Percival)

Minylitha convallis Bukry

Reticulofenestra pseudoumbilica (Gartner)

Sphenolithus abies Deflandre
S. neoabies Bukry and Bramlette

Triquetrorhabdulus rugosus Bramlette and Wilcoxon

\section{ACKNOWLEDGMENT}

I thank Naja Mikkelsen, Scripps Institution of Oceanography, and John Barron, U.S. Geological Survey, for their critical review of this paper. Jim Natland and Jim Kirkpatrick, both of Deep Sea Drilling Project, kindly provided shipboard samples and helpful descriptions of the sediment and coring operations.

\section{REFERENCES}

Bukry, D., 1973. Low-latitude coccolith biostratigraphic zonation. In Edgar, N. T., Saunders, J. B., et al., Initial Reports of the Deep Sea Drilling Project, v. 15: Washington (U.S. Government Printing Office), p. 685703.

1975. Coccolith and silicoflagellate stratigraphy, northwestern Pacific Ocean, Deep Sea Drilling Project Leg 32. In Larson, R. L., Moberly, R., et al., Initial Reports of the Deep Sea Drilling Project, v. 32: Washington (U.S. Government Printing Office), p. 677701.

Dmitriev, L. V., Heirtzler, J. R., et al., 1976. Drilling into ocean crust east of the Mid-Atlantic Ridge: Geotimes, v. 21 , p. $21-23$.

Gartner, S. and Bukry, D., 1975. Morphology and phylogeny of the coccolithophycean family Ceratolithaceae: U.S. Geol. Survey J. Research, v. 3, p. 451-465.

Hay, W. W. and Beaudry, F. M., 1973. Calcareous nannofossils-Leg 15, Deep Sea Drilling Project. In Edgar, N. T., Saunders, J. B., et al., Initial Reports of the Deep Sea Drilling Project, v. 15: Washington (U. S. Government Printing Office), p. 625-683.

Hay, W. W., Mohler, H., Roth, P. H., Schmidt, R. R., and Boudreaux, J. E., 1967. Calcareous nannoplankton zonation of the Cenozoic of the Gulf Coast and CaribbeanAntillean area, and transoceanic correlation: Gulf Coast Assoc. Geol. Soc. Trans., v. 17, p. 428-480.

Norris, R. E., 1971. Extant calcareous nannoplankton from the Indian Ocean. Second Planktonic Conf. Proc., p. 899909.

Rabinowitz, P. A., Melson, W. G., et al., 1976. Challenger drills on Leg 45 along the Mid-Atlantic Ridge: Geotimes, v. 21 , p. $20-23$.

van Andel, Tj. H. and Bukry, D., 1973. Basement ages and basement depths in the Eastern Equatorial Pacific from Deep Sea Drilling Project Legs 5, 8, 9, and 16: Geol. Soc. Am. Bull., v. 84 , p. 2361-2370. 

PLATE 1

Neogene Coccoliths from DSDP Legs 30, 45, and 46.

Cross-polarized light micrographs designated (XP); other illustrations are bright field.

Figures 1-6, 9, 10, 13-18 magnified 1000×; scale bar equals

$10 \mu \mathrm{m}$.

Figure 25 magnified $450 \times$; scale bar equals $10 \mu \mathrm{m}$.

Figure 26 magnified $800 \times$; scale bar equals $10 \mu \mathrm{m}$.

Figures 7, 8, 11, 12, 19, 20 magnified 1200×; scale bar equals $10 \mu \mathrm{m}$.

Figures 21-24 magnified 1900×; scale bar equals $5 \mu \mathrm{m}$.

Figures 1-16 Ceratolithus separatus n. sp.

1, 2. USNM 245106, Sample 395-4-1, $70 \mathrm{~cm}$ (27 $\mathrm{m})$. 2. XP.

3, 4. USNM 245107, Sample 396-2-1, $120 \mathrm{~cm}$ (6 m). 4. XP.

5, 6. Holotype, USNM 245105, Sample 396$7-2,75 \mathrm{~cm}(54 \mathrm{~m}) .6$. XP.

7, 8. USNM 245108, Sample 395-4-1, $70 \mathrm{~cm}$ $(27 \mathrm{~m}) .8$. XP.

9, 10. USNM 245109, Sample 395-4-1, $70 \mathrm{~cm}$ $(27 \mathrm{~m}) .10 . \mathrm{XP}$.

11, 12. USNM 245110, Sample 396-7-2, $75 \mathrm{~cm}$ $(54 \mathrm{~m}) .12$. XP.

13. USNM 245111, Sample 395-4-1, $70 \mathrm{~cm}$ (27 $\mathrm{m}), \mathrm{XP}$.

14. USNM 245112, Sample 396-7-2, $75 \mathrm{~cm}$ (54 $\mathrm{m})$.

15, 16. USNM 245113, on left, Sample 395-9-2, $75 \mathrm{~cm}(77 \mathrm{~m})$; Ceratolithus rugosus Bukry and Bramlette on right. 15. XP.

Figures 17-26 Ceratolithus simplex n. sp.

17. USNM 245115 , Sample $395 \mathrm{~A}-1-2,2-3 \mathrm{~cm}$ (4 $\mathrm{m})$.

18 USNM 245116, Sample 287-1-2, 95-96 cm (1 $\mathrm{m}), \mathrm{XP}$.

19, 20. Holotype, USNM 245114, Sample 396-1, CC $(5 \mathrm{~m}) .20 . \mathrm{XP}$.

21,22 . USNM 245117, Sample 395A-1-2, 2-3 $\mathrm{cm}(4 \mathrm{~m}) .22$. XP.

23, 24. USNM 245118, Sample 395A-1-2, 2-3 $\mathrm{cm}(4 \mathrm{~m}) .24$. XP.

25. USNM 245119, on left, Sample 287-1-2, 95$96 \mathrm{~cm}(1 \mathrm{~m})$; Ceratolithus cristatus Kamptner on right for comparison of size and shape, XP.

26. USNM 245120 , on left, Sample 395A-2, CC (3 m);C. cristatus on right. 
PLATE 1
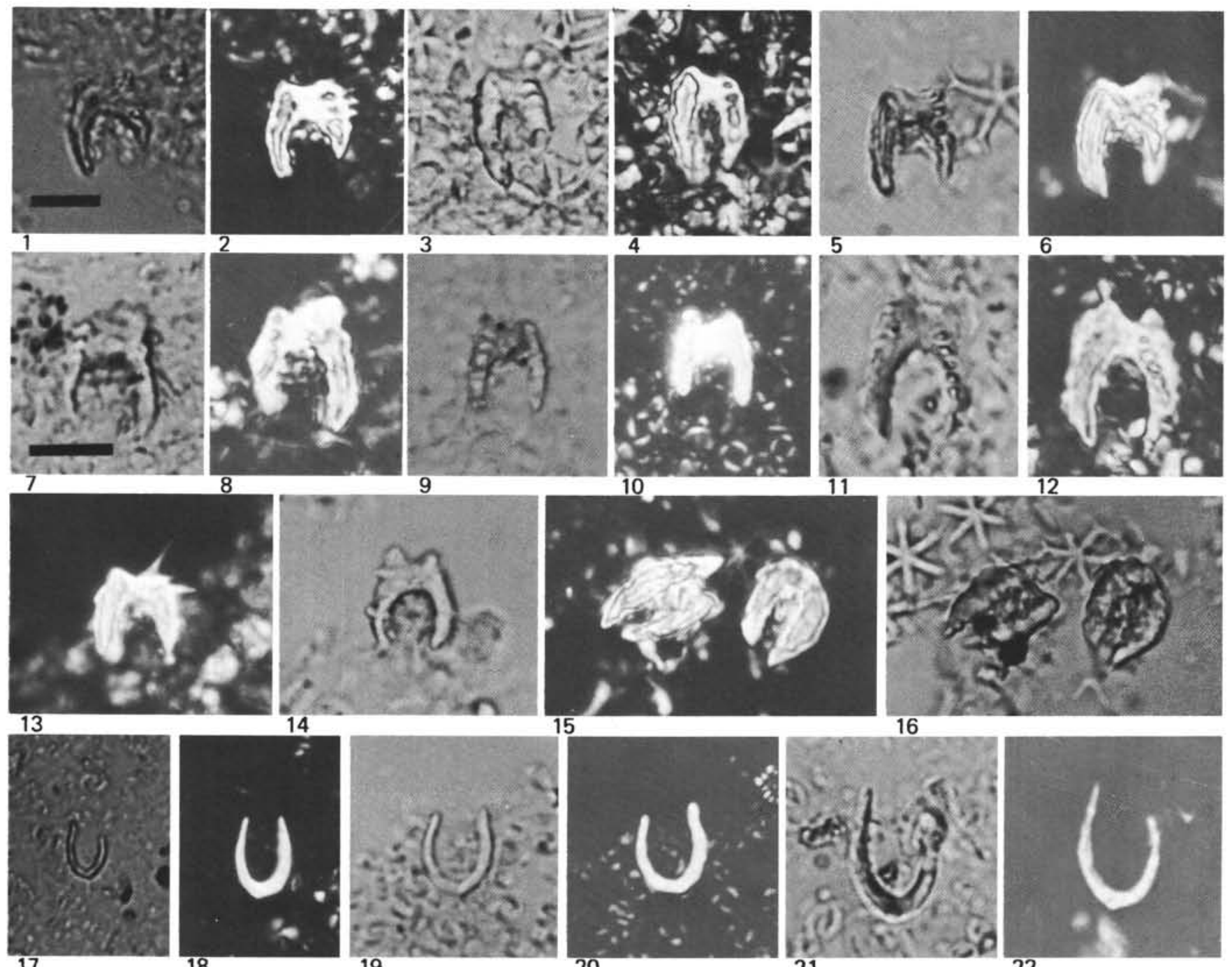

16
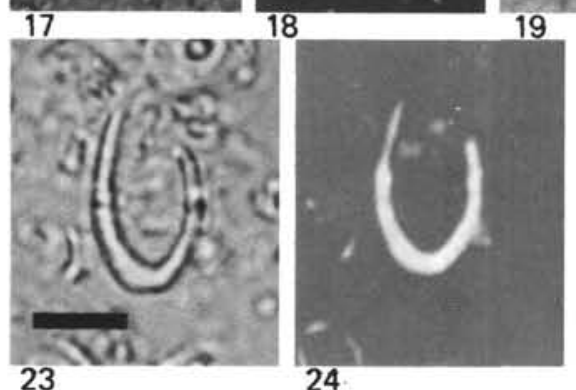

24
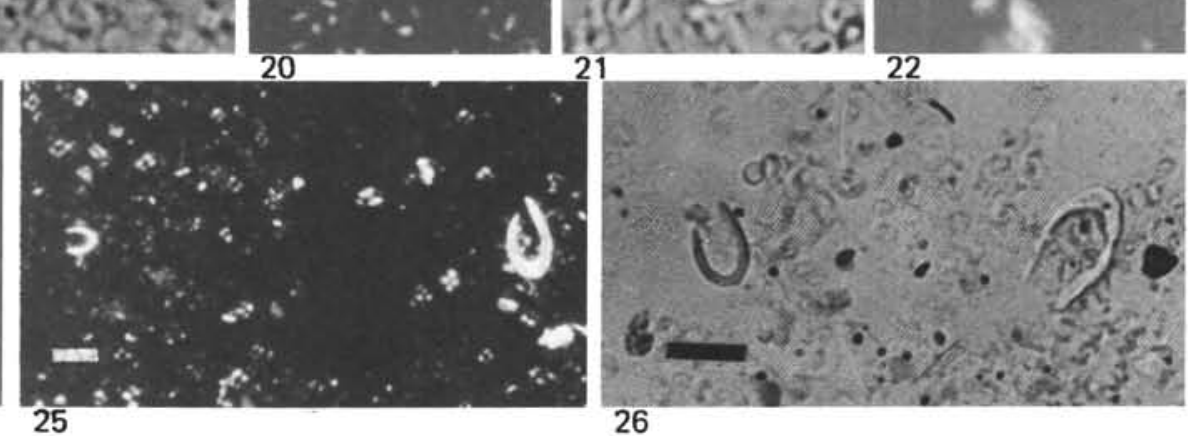
PLATE 2

Neogene Coccoliths from DSDP Legs 30, 45, and 46.

Cross-polarized light micrographs designated (XP), other illustrations are bright field.

Figures 1, 3, 4, 6-8, 11 magnified $1000 \times$; scale bar equals 10 $\mu \mathrm{m}$.

Figures 2, 9, 10 magnified $800 \times$; scale bar equals $10 \mu \mathrm{m}$.

Figure 5 magnified $1900 \times$; scale bar equals $5 \mu \mathrm{m}$.

Figure $1 \quad$ Amaurolithus bizzarus (Bukry). Sample 395-6, CC (49 m).

Figure 2 Amaurolithus sp. cf. A. tricorniculatus (Gartner). Sample 396-12-2, $75 \mathrm{~cm}(100 \mathrm{~m})$.

Figures 3, 4 Ceratolithus acutus Gartner and Bukry. Sample 395-9, CC (84 m).

3. Two small placoliths visible, XP.

4. Same field of view, many kinds of discoasters and discoaster rays visible.

Figures 5, 6 Ceratolithus cristatus Kamptner.

5. Sample 395A-1-2, 2-3 cm (4 m), XP.

6. Sample 287-1-2, 95-96 cm (1 m), XP.

Figure 7 Ceratolithus telesmus Norris.

Sample 287-1-2, 95-96 cm (1 m), XP.

Figures 8-11 Coccolith assemblages.

8. Middle or upper Pliocene, Sample 395-6-2, $90 \mathrm{~cm}(47 \mathrm{~m})$.

9, 10. Upper Miocene, Sample 396-5-3, $108 \mathrm{~cm}$ $(37 \mathrm{~m})$, brown bleb.

11. Middle Miocene, Sample 396-14-6, 5-6 cm $(125 \mathrm{~m})$. 
PLATE 2
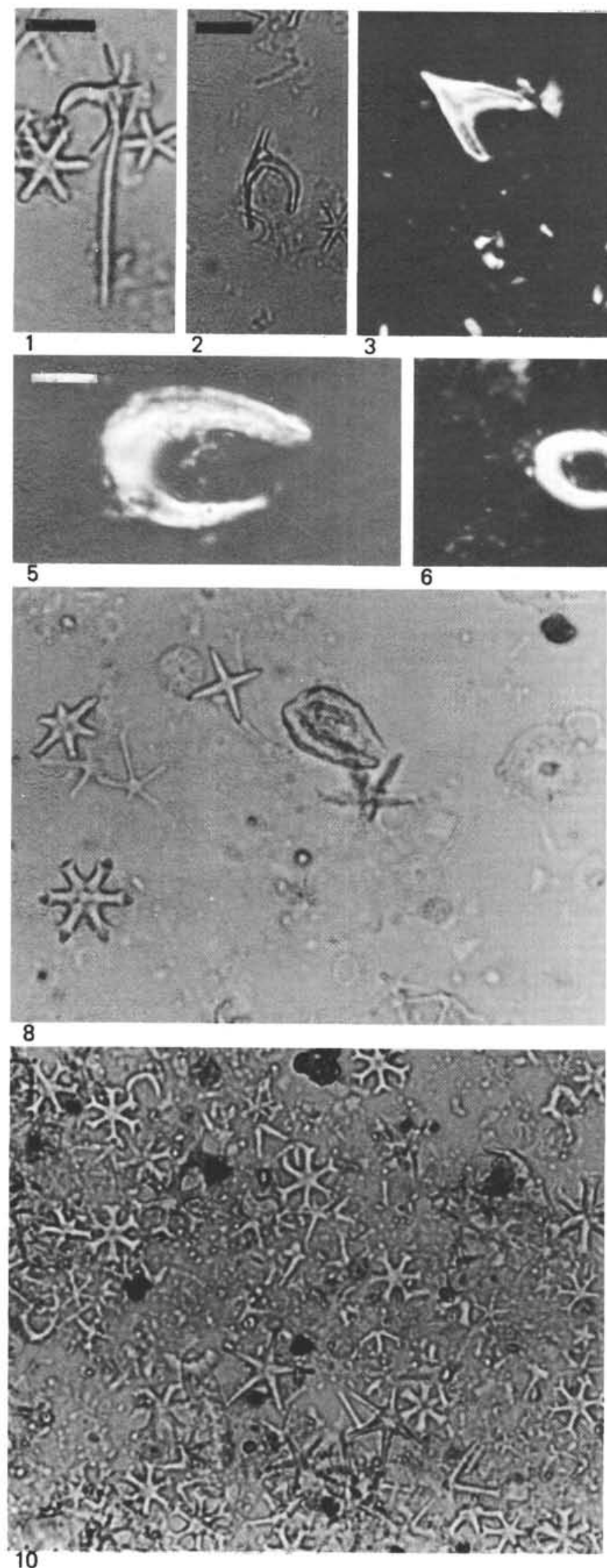
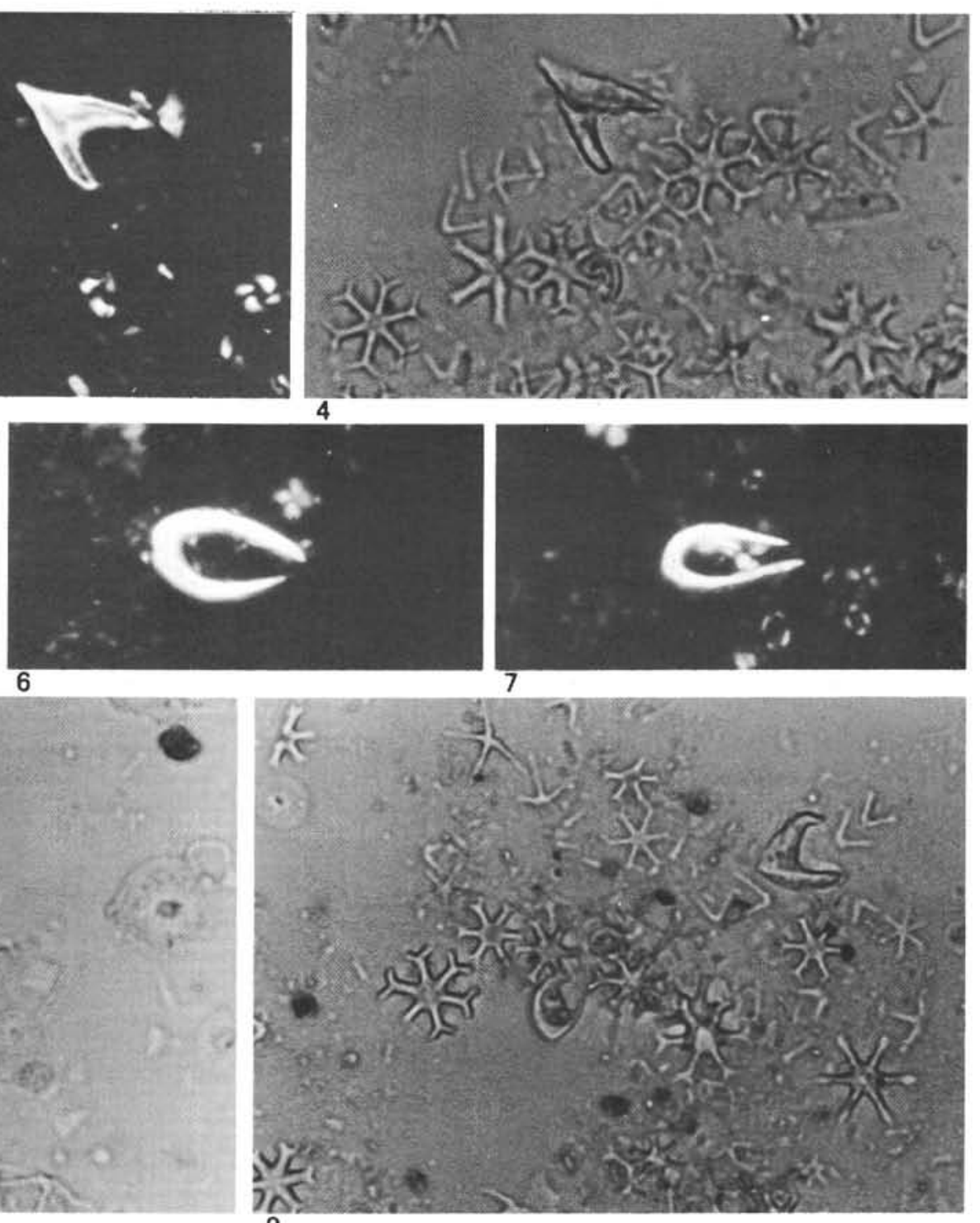

9

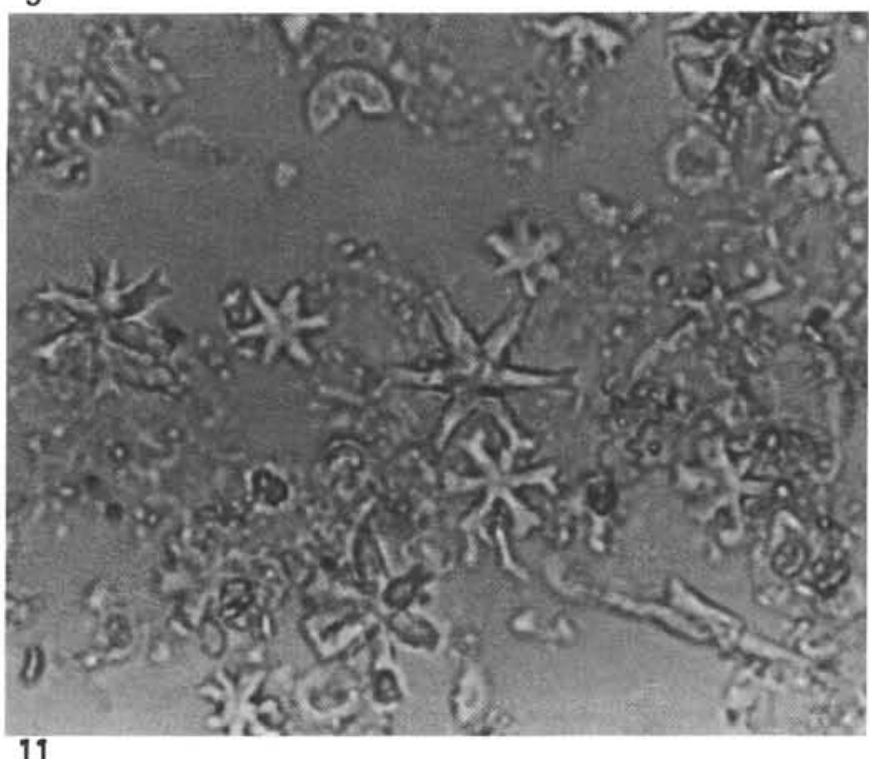

